\title{
How Young Companies Can Build Online Communities
}

\section{Sofia Bapna (Carlson School of Managemet, University of Minnesota)}

\author{
KEYWORDS: Social Media \& Networks, \\ Entrepreneurship, Information Technology.
}

\section{By Sofia Bapna, Mary J. Benner and Liangfei Qiu}

Online social media communities have helped companies build customer loyalty and sales, but new firms starting from scratch to build those communities often don't know how to attract social media fans and sustain their interest. Our study (https://papers.ssrn.com/sol3/papers.cfm?abstract_id= 3043604), published in MIS Quarterly in 2017, removes some of the mystery.

We propose that a pied-piper effect attracts newcomers (and potential new customers) to a company's online community. When individuals engage with a company's post, for example by "liking" or commenting on the post, the social media platform automatically spreads information about this interaction and the related company content to the individual's friends and followers. Based on the new information they receive about the company, these friends and followers may join the community themselves. New members (and existing community members) may engage with subsequent company posts, which may lead to a bigger social media following.

It can be challenging for young firms to know which kinds of company posts are likely to generate the most engagement, and in turn grow the community. We took an in-depth look at the kinds of posts that generated the most "likes." Unlike many studies that have used automated natural language processing (NLP) to analyze post content, we manually examined post content and caught nuances that a NLP based analysis would have missed. Our insights can be useful to new companies that want to build an online following quickly.

\section{What we measured}

Our study looked at 15 young retailers and their 9,470 posts from 2010 through 2012. The posts were from the companies' own Facebook brand pages and all the companies were founded in 2010 . Thus we examined the companies' early social media activity.
We collected all company post content, engagement ("likes") in response to the posts, and weekly data on online community size. Our study used Amazon's Mechanical Turk workers to manually analyze and categorize the content of company posts along 13 different dimensions in two broad categories: posts that shaped perceptions and those that offered monetary incentives. Posts that shaped perceptions included those that conveyed firm credibility, professional organizing and organizational achievements, and posts that sought opinions. Posts that offered monetary incentives included those that conveyed information about sales, offers or promotions and those about contests. Because humans categorized the post content, we were able to consider video content, blog content, text embedded in images, and what the images in photos communicated. We used this data to analyze the association between different types of post content and engagement. We also examined the association between engagement and online brand community growth.

\section{Findings}

Our study confirmed that engagement with a company's posts helped increase the size of the online community. Engagement increased when posts shaped perceptions or offered a monetary incentives. In particular, we saw increased engagement from posts that conveyed firm credibility through product and industry knowledge; provided information about firm milestones, partnerships, or awards; sought opinions; or offered a sales or promotion. Posts that offered tips or suggestions, industry information, design origin information and collections or picks helped demonstrate a company's product and industry knowledge and increase engagement.

\section{The Takeaway}

Start Early - Young firms that want to grow their online communities should use four major posting strategies: convey firm credibility; convey organizational 
achievements, offer promotions or cost savings and seek opinions. Our study found that these strategies will pay off most dramatically for companies whose online presence is less than 18 months old.

Advice for Companies Selling Niche Products - In general, sharing information about organizational achievements -- through posts about firm milestones, partnerships or awards -- will have the most benefit for companies that sell niche products. These companies can also benefit from posts that show off their product knowledge, by showcasing special "collections" or "picks" or sharing information about the product's designer, manufacturer, stylist, curator or place of origin.

\begin{abstract}
Advice for Companies Selling Mass Appeal Products -- In contrast, firms that are introducing products that are expected to have mass appeal can increase engagement with posts that convey industry knowledge, with news, anecdotes or feature articles about the industry. These companies can also build engagement with their communities by asking questions, taking polls and offering a promotion, discount, award or special offer.
\end{abstract}

\title{
Read More
}

Nurturing Online Communities: An Empirical Investigation

(https://papers.ssrn.com/sol3/papers.cfm?abstract_id= 3043604)

Additional Search Terms: Online community, social media, online brand community, sensegiving, sensemaking, influencing perceptions, monetary incentives 